\title{
Radioimmunoassay of cholecystokinin-pancreozymin ${ }^{1}$
}

\author{
R. F. HARVEY, LYNDA DOWSETT, M. HARTOG, AND A. E. READ \\ From the Department of Medicine, University of Bristol, Bristol Royal Infirmary, Bristol
}

SUMMARY A sensitive and specific radioimmunoassay for cholecystokinin-pancreozymin (CCK-PZ) has been developed, using rabbit antisera to crude porcine hormone. Highly purified porcine CCK-PZ, labelled with ${ }^{131}$, and repurified by column chromatography on Sephadex G15, was used as tracer. Separation of free from antibody-bound labelled CCK-PZ was carried out using charcoal, ion-exchange resin, or a double antibody procedure. Non-specific interference with the assay system by serum factors was abolished (as judged by in-vitro and in-vivo recovery studies) by boiling and diluting the serum samples before assay. Ninety-nine per cent pure porcine CCK-PZ (standard), commercial CCK-PZ preparations, caerulein, the C-terminal 8- and 12-amino acid fragments of the CCK-PZ molecule, and endogenous human CCK-PZ all cross reacted in the assay system and showed parallel inhibition curves. No significant cross reaction was found with gastrin, secretin, glucagon, or insulin. The sensitivity of the assay is approximately $5 \mathrm{pg}$ per $\mathrm{ml}$ of test solution, which proved adequate for measuring physiological levels of CCK-PZ in peripheral blood in man.

The mean immunoreactive CCK-PZ concentration in 50 fasting normal subjects was $60.4 \mathrm{pg}$ per $\mathrm{ml}$. The distribution of individual values was skewed, however, so that the median was much lower (30 pg per $\mathrm{ml}$ ). Older subjects had higher fasting levels of CCK-PZ than were found in young adults.

Originally believed to be two separate hormones, cholecystokinin-pancreozymin (CCK-PZ) has recently been characterized as a single peptide (Jorpes and Mutt, 1966). It is released from the small-intestinal mucosa after food and has a number of important actions on the gastrointestinal tract. The best documented of these are stimulation of gallbladder contraction ('cholecystokinin') (Ivy and Oldberg, 1928), pancreatic enzyme secretion ('pancreozymin') (Harper and Raper, 1943), small-intestinal secretion of fluid (Moritz, Finkelstein, Meshkinpour, Fingerut, and Lorber, 1973) and enzymes (Nasset, 1972; Dyck, Hall, and Ratliff, 1973), small intestinal (Adlercreutz, Pettersson, Adlercreutz, Gribbe, and Wegelius, 1960; Dahlgren, 1966) and large intestinal (Grossi, Messini, Del Duca, Ricci, and Messini, 1966; Harvey and Read, 1973; Dinoso, Meshkinpour Lorber, Gutierrez, and Chey, 1973) motility, and contraction of the pylorus (Fisher, Lipshutz, and Cohen, 1973) with an associated decrease in the rate of gastric emptying (Chey, Hitanant, Hendricks, and Lorber, 1970). Studies of the release and actions of

Received for publication 30 April 1974.

${ }^{1}$ Presented in part at the 20th Symposium, Deutsche Gesellschaft für Endokrinologie, Tübingen, 28 Feb 1974.
CCK-PZ have been hampered by the lack of a suitable method for its assay in serum. Several previous groups have described the production of antibodies to CCK-PZ (Young, Lazarus, Chisholm, and Atkinson, 1969; Go, Ryan, and Summerskill, 1972; Berson and Yalow, 1972; Reeder, Becker, Smith, Rayford, and Thompson, 1973; Harvey, Dowsett, Hartog, and Read, 1973; Englert, 1973) but the various stages required for the development and characterization of a radioimmunoassay suitable for the measurement of physiological levels of the hormone in human serum have not previously been described in detail. This paper describes the development of a radioimmunoassay suitable for the study of CCK-PZ secretion in man under physiological conditions and in disease states.

\section{Methods}

PRODUCTION OF ANTISERA

Immunization of guinea-pigs, rabbits, and sheep was carried out over a two-year period, using relatively impure preparations of porcine CCK-PZ as antigen. Two different sources of CCK-PZ were used. A large batch of pancreozymin (Boots 
Company Ltd, Nottingham), blend 44 , specific activity approximately 5 Crick, Harper, and Raper (CHR) units per mg, was given by courtesy of $\mathrm{Mr}$ V. J. Birkinshaw and Dr J. Warwick Buckler. Vitrum cholecystokinin was purchased from the G.I.H. Research Laboratory, Karolinska Institute, Stockholm, and was estimated by them to contain approximately $16 \%$ cholecystokinin by weight. Some details of the immunization programme are shown in the table. All injections were given in Freund's complete adjuvant.

\section{Guinea pigs}

All guinea-pig inımunizations and bleedings were carried out in the Bioassay Laboratory of Boots Company Ltd under the direction of $\mathrm{Mr} \mathrm{V}$. J. Birkinshaw, head of that department. Initially 25 animals received injections each of $90 \mathrm{CHR}$ units of pancreozymin (Boots) in Freund's complete adjuvant, given into multiple sites at monthly intervals. No antibodies could be detected after six injections. Larger doses, of $750 \mathrm{CHR}$ units, were then given to each of 10 guinea pigs approximately every two weeks for a further six months, and antibodies were detected in two animals at the end of this time. Repeated injections failed to boost the antibody titre significantly.

\section{Rabbits}

Six rabbits received injections of Vitrum cholecystokinin (approximately 350 Ivy dog units (IDU) per injection) at two-monthly intervals. Despite varying the sites of injection, eg, into popliteal lymph nodes in two animals, and injecting intramuscularly, subcutaneously, and at multiple intradermal sites at different times in the remainder, no antibodies were detected after one year. Antibodies were, however, produced in three of six rabbits given monthly injections of $600 \mathrm{CHR}$ units of pancreozymin (Boots) for six months. Two of these antisera were suitable for use in a radioimmunoassay system for CCK-PZ. Repeated injections over a further 18-month period have maintained but failed to boost the antibody titre in these three animals.

\section{Sheep}

Four sheep were immunized under the direction of Dr F. J. Bourne of the Veterinary Research Station, Langford, Somerset. Injections were given at irregular intervals over a two-year period. Two animals received pancreozymin (Boots), and neither produced detectable antibodies. Antibodies suitable for use in an immunoassay system were produced after one year of immunization by one of the two sheep given Vitrum cholecystokinin (see table).

Although with the methods used in this study

\begin{tabular}{|c|c|c|c|}
\hline Species & $\begin{array}{l}\text { No.of } \\
\text { Animals }\end{array}$ & Antigen Employed & $\begin{array}{l}\text { Number of Animals } \\
\text { with Antibodies } \\
\text { Detectable at } \\
>1: 100 \text { Dilution }\end{array}$ \\
\hline Guinea pig & 25 & $\begin{array}{l}\text { Pancreozymin (Boots) } \\
\text { (c } 90 \text { CHR units per dose) }\end{array}$ & 0 \\
\hline Guinea pig & 10 & $\begin{array}{l}\text { Pancreozymin (Boots) } \\
\text { (c } 750 \text { CHR units per dose) }\end{array}$ & 2 \\
\hline Rabbit & 6 & $\begin{array}{l}\text { Vitrum cholecystokinin } \\
\text { (c } 350 \text { IDU per dose) }\end{array}$ & 0 \\
\hline Rabbit & 6 & $\begin{array}{l}\text { Pancreozymin (Boots) } \\
\text { (c } 600 \text { CHR units per dose) }\end{array}$ & 3 \\
\hline Sheep & 2 & $\begin{array}{l}\text { Vitrum cholecystokinin } \\
\text { (c } 350 \text { IDU per dose) }\end{array}$ & 1 \\
\hline Sheep & 2 & $\begin{array}{l}\text { Pancreozymin (Boots) } \\
\text { (c } 1200 \text { CHR units per dose) }\end{array}$ & 0 \\
\hline
\end{tabular}

Table Production of antisera to CCK-PZ

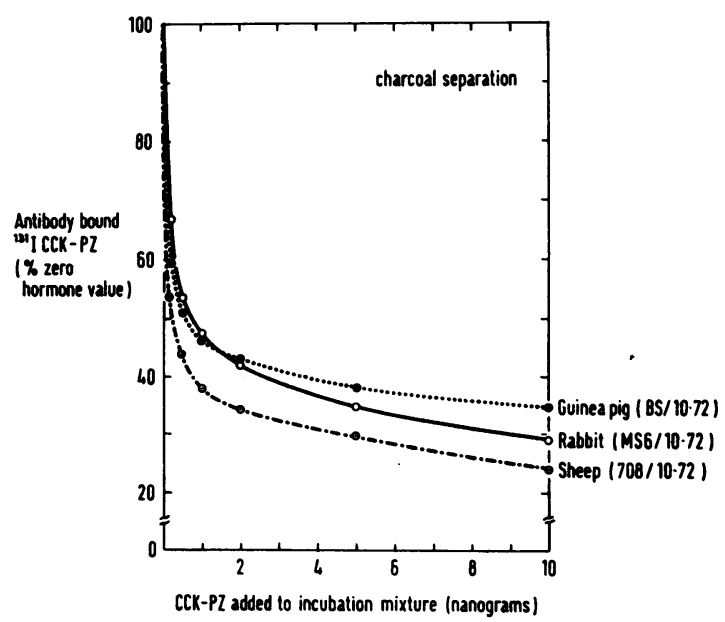

Fig 1 Standard curves obtained with antisera from three different species and using charcoal to separate free from antibody-bound ${ }^{131} I C C K-P Z$. For comparative purposes antibody binding is expressed as a percentage of the binding observed when no non-radioactive CCK-PZ was present in the incubation mixture. (Antibody dilutions 1:100 for sheep and guinea-pig antisera and 1:300 for the rabbit antiserum.)

rabbits appeared to produce detectable antibodies to CCK-PZ more frequently than did guinea-pigs (see table), antisera were obtained from each of the three species immunized which, although low in titre (binding between $15 \%$ and $35 \%$ of tracer amounts of ${ }^{131}$ I-labelled CCK-PZ at the antibody dilutions stated), were of high avidity in each case, as indicated by the relatively steep initial slope of the standard curves (fig 1). Of interest was the fact that repeated immunization of antibody-producing animals failed to produce any appreciable rise in antibody titre. A similar phenomenon in the case of 
antisera to gastrin was reported by Yalow and Berson (1970).

\section{PREPARATION OF RADIOACTIVELY LABELLED} CCK-PZ

Very highly purified cholecystokinin was received as a gift from Professor Viktor Mutt, GIH Research Laboratory, Karolinska Institute, Stockholm (batch of 11 November 1970, estimated purity $99 \%$, specific activity approximately 3000 Ivy dog units per $\mathrm{mg}$ ). This was labelled with radioiodine (Radiochemical Centre, Amersham) using a modification of the chloramine-T method (Hunter and Greenwood, 1962). Forty $\mu 1$ of Sorensen's phosphate buffer, $0.05 \mathrm{M}, \mathrm{pH} 7 \cdot 4$, containing $500 \mathrm{ng}$ of highly purified CCK-PZ, was placed in a $5 \times 30 \mathrm{~mm}$ glass tube. Five hundred $\mu \mathrm{Ci}$ of radioactive iodine and $20 \mu \mathrm{g}$ of chloramine-T in $10 \mu \mathrm{l}$ phosphate buffer were then added with mixing. After 15 to 30 seconds $50 \mu \mathrm{g}$ of sodium metabisulphite in $10 \mu \mathrm{l}$ phosphate buffer was added and the reaction mixture diluted with a solution of $2 \mathrm{mg}$ potassium iodide in $200 \mu \mathrm{l}$ and transferred to the top of a $1 \times 15 \mathrm{~cm}$ Sephadex column previously washed through with $0.05 \mathrm{M}$ phosphate buffer. The reaction vessel was washed with a further $200 \mu \mathrm{l}$ of potassium iodide solution which was also transferred to the Sephadex column. The column was then eluted with the same phosphate buffer as used throughout. Labelled CCK-PZ was eluted in a single peak immediately after the void volume (fig 2), and after suitable dilution could be used directly in the assay system.

Both ${ }^{125}$ I and ${ }^{131}$ I were found suitable for iodina-

G15 SEPHADEX COLUMN, $1 \times 15 \mathrm{~cm}$ ELUTEO WITH 0.05M PHOSPHATE BUFFER, PH 7.4

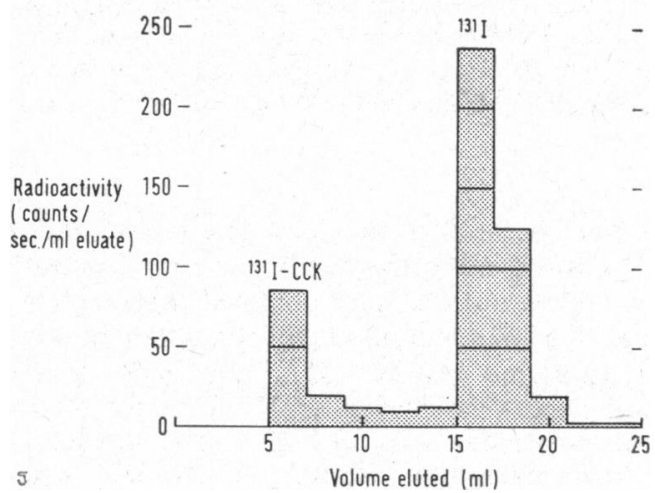

Fig 2 Separation of ${ }^{131}$ I-labelled cholecystokininpancreozymin from ${ }^{131} I$ after radioiodination. ${ }^{131}$ I CCK-PZ elutes as a single peak immediately after the void volume. tion. The labelled hormone appeared to be somewhat unstable on storage, as shown by a progressive decrease in antibody binding with time. ${ }^{131}$ I was routinely used for labelling, at fortnightly intervals. In general, specific activities achieved were relatively low, being usually between 30 and $100 \mu \mathrm{Ci}$ per $\mu \mathrm{g}$ of CCK-PZ. Higher specific activities were occasionally achieved, but often at the expense of apparent damage to the labelled hormone, as shown by relatively poor antibody binding, and occasionally by elution of the labelled peptide in two separate peaks, one presumably representing damaged hormone.

CONDITIONS OF INCUBATION AND SEPARATION OF ANTIBODY-BOUND FROM FREE HORMONE

Four methods have been used to detect antibodies to CCK-PZ and for separation of antibody-bound from free labelled hormone. For each of the first three methods the final volume of the incubation mixture was $300 \mu \mathrm{l}$. Serum samples were usually diluted 1:20 in Sorensen's phosphate buffer, 0.05M, $\mathrm{pH} 7 \cdot 4$, and thus assayed at a final dilution of $1: 60$ in the incubation mixture. Standard solutions of CCK-PZ and other peptides were made up either in the same phosphate buffer or else in human serum devoid of detectable hormone, diluted 1:20 in phosphate buffer, and added in a volume of $100 \mu \mathrm{l}$. 131I CCK-PZ (1-10 pg in $100 \mu$ l phosphate buffer) and diluted antiserum (dilution depending on the antiserum used) were each added in volumes of $100 \mu \mathrm{l}$. Mixtures were incubated at $4^{\circ} \mathrm{C}$ for 48 hours before separation of antibody-bound from free hormone.

\section{Charcoal separation ( fig I)}

Free labelled CCK-PZ is adsorbed by charcoal, whereas antibody-bound hormone is not. Separation was achieved by adding to the incubation mixture $1.0 \mathrm{ml}$ of $0.05 \mathrm{M}$ phosphate buffer, $\mathrm{pH} 7.4$, containing $5.0 \mathrm{mg}$ of charcoal (Norit OL) and $0.25 \mathrm{mg}$ dextran (Dextran T70, Pharmacia). After mixing and centrifugation at $2000 \mathrm{rpm}$ for 30 minutes, the supernatant solution, containing the antibody-bound hormone, was decanted and both free and bound fractions of ${ }^{131}$ I CCK-PZ were counted in an automatic well-type scintillation counter. This method was not found entirely satisfactory when used with serum samples, because of interference by serum proteins, and was in general used only for studies of protein-free samples.

\section{Ion-exchange resin}

Separation of free from antibody-bound labelled CCK-PZ may be carried out using $5 \mathrm{mg}$ Amberlite CG-400, type II, 200 mesh, ion-exchange resin 
(Rohm and Hass Ltd) which adsorbs the free but not the antibody-bound hormone, suspended in $1.0 \mathrm{ml}$ of $0.05 \mathrm{M}$ phosphate buffer. After brief mixing and centrifugation at $2000 \mathrm{rpm}$ for 30 minutes, the resin was well packed and the supernatant could be decanted. Both fractions were then counted in the same way as used for the charcoal separation.

\section{Second antibody method (figs 3 and 4)}

After the initial 48-hour incubation, $100 \mu l$ of precipitating antiserum (Wellcome Reagents Ltd) was added and the mixture incubated for a further 16 hours. Antibody-bound ${ }^{131}$ I CCK was precipitated, and after centrifugation at $\mathbf{2 0 0 0} \mathrm{rpm}$ for $\mathbf{3 0}$ minutes the supernatant was decanted and the antibodybound hormone counted. This method was only used with rabbit antisera to CCK-PZ, employing a donkey antirabbit precipitating second antibody.

\section{Pre-precipitated second antibody method}

All three of the separation methods described above were subject on occasions to nonspecific interference. This appeared in most instances to be due to serum proteins, and with charcoal and resin separation methods could largely be abolished by diluting the serum or by boiling it prior to assay (as described below). In the case of the second antibody separation pre-precipitation of antibody to CCK-PZ, as described by Hales and Randle (1963), was found to abolish nonspecific interference with the assay with all but a small minority of sera. This was the technique used routinely for assay of CCK-PZ in serum samples. Two hundred $\mu$ l of suitably diluted antiserum (MS6, final dilution 1:400 in Sorensen's phosphate buffer, $0.05 \mathrm{M}, \mathrm{pH} 7.4$ ) was incubated with $100 \mu \mathrm{l}$ precipitating antiserum (donkey antirabbit, Wellcome Reagents Ltd) in glass tubes $10 \times 55 \mathrm{~mm}$ at $4^{\circ} \mathrm{C}$ for 16 hours. One hundred $\mu l$ of standard solutions (containing dilutions of highly purified 'standard' porcine CCK-PZ in hormone-free human serum, boiled and diluted 1:20) or of unknown serum samples also diluted 1:20 were then added, together with $10 \mu \mathrm{l}$ of labelled CCK-PZ (1-10 pg) in phosphate buffer. The mixture was then incubated at $4^{\circ} \mathrm{C}$ for 48 hours. After centrifuging at $2000 \mathrm{rpm}$ for 30 minutes the supernatant was decanted and the amount of radioactive CCK-PZ bound by the precipitated antibody measured. All samples were assayed in triplicate.

\section{Results}

\section{SENSITIVITY OF ASSAY}

Using the rabbit antiserum MS6, at a final dilution in the incubation mixture of $1: 400$, the initial slope of the standard curve was very steep (fig 3 ), in-

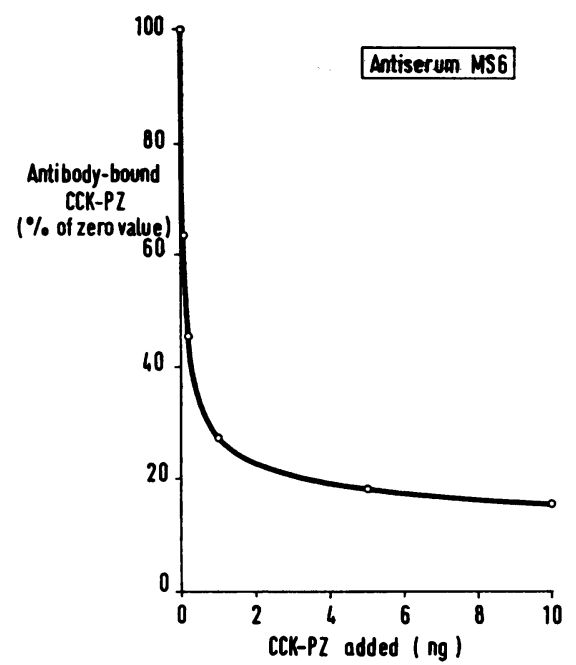

Fig 3 Standard curve using the rabbit antiserum (MS6), which was the antiserum used to develop the CCK-PZ assay. Separation of free from antibody-bound labelled $C C K-P Z$ was in this case carried out using a second antibody procedure. For comparison with fig 1 antibodybound ${ }^{131}$ I CCK-PZ is expressed as a percentage of the value obtained when no non-radioactive hormone was added. The first three points on the standard curve were produced by the addition of 10,100 , and $1000 \mathrm{pg}$ of very highly purified $C C K-P Z$ to the incubation mixture.

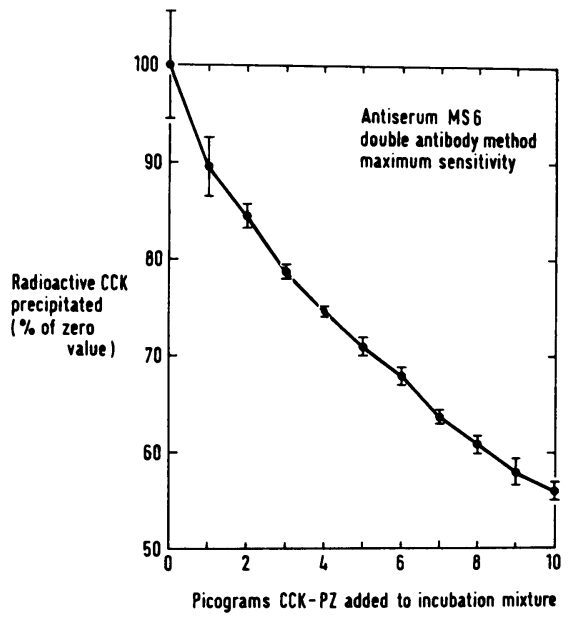

Fig 4 Standard curve using rabbit antiserum MS6 with a double-antibody separation and ${ }^{131}$ I CCK-PZ of high specific activity at a lower concentration than usual. Points are means and standard errors of triplicate determinations in a single assay. 
dicating a high degree of sensitivity. More detailed studies of this initial part of the standard curve (fig 4) showed that the addition of as little as $1 \mathrm{pg}$ of very highly purified CCK-PZ to the incubation mixture produced an easily detectable fall in antibody binding.

The average variation (as standard deviation) of the triplicates in six separate determinations of the percentage binding at $0 \mathrm{pg}$ per $\mathrm{ml}$ (tracer hormone only) was $3.3 \%$ : the addition of $1 \mathrm{pg}$ of CCK-PZ produced an average inhibition of binding of $17 \cdot 3 \%$. As this corresponds to a concentration in the unknown sample of $10 \mathrm{pg}$ per $\mathrm{ml}(1 \mathrm{pg}$ in $100 \mu \mathrm{l})$ it can be estimated that the sensitivity of the assay, as defined by Ekins, Newman, and O'Riordan (1968), is approximately $5 \mathrm{pg}$ per $\mathrm{ml}$.

\section{SPECIFICITY}

Because the C-terminal pentapeptide amide sequence of CCK-PZ is identical with the corresponding sequence on the gastrin molecule (Jorpes and Mutt, 1973), antibodies directed at this region may cross react with gastrin to such an extent that the value of an assay is seriously diminished (McGuigan, 1968). Studies were therefore carried out to assess cross reactivity with gastrin, and also in an attempt to determine the main site of interaction between the rabbit antibody (MS6) and the CCK-PZ molecule.

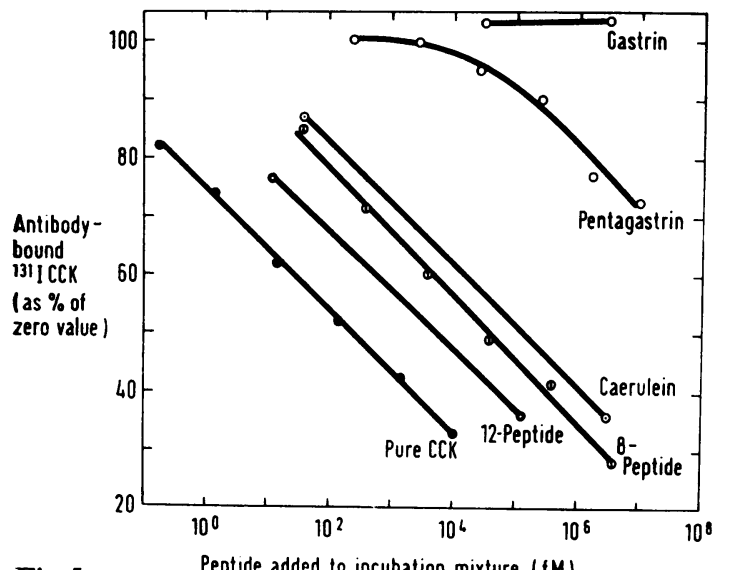

Fig 5 Peptide added to incubation mixture $(\mathbb{I M})$
The results of these studies are shown in figures 5 and 6. C-terminal 8-and 12-aminoacid fragments of the CCK-PZ molecule (kindly given by Dr M. Ondetti and colleagues, the Squibb Institute for Medical Research, New Brunswick) (Ondetti, Rubin, Engel, Pluščec, and Sheehan, 1970; Ondetti, Pluščec, Sabo, Sheehan, and Williams, 1970), and the C-terminal decapeptide CCK-PZ analogue caerulein (Farmitalia Ltd) (Anastasi, Erspamer, and Endean, 1968), all showed inhibition curves parallel with that of highly purified porcine CCK-PZ. Pentagastrin (ICI Ltd) showed only very slight cross reaction, and gastrin (synthetic human gastrin I, ICI Ltd, given by courtesy of Dr J. S. Morley) showed none at all. As would be expected, structurally dissimilar hormones such as secretin, glucagon, and insulin also showed no significant cross reaction.

\section{STANDARDS FOR RADIOIMMUNOASSAY}

Suitably characterized reference standards of known stability and biological potency are not yet available for any species of CCK-PZ. Even in the case of the porcine hormone there is no certain evidence that the very highly purified hormone (estimated by Professors Jorpes and Mutt to be approximately $99 \%$ pure) represents the ultimate in purity and potency. The standard preparation used for reference

Fig 5 Cross reactivity in the assay system of different CCK-PZ analogues, expressed on a molar basis. The bottom scale is logarithmic. All peptides showing cross reaction produce inhibition curves which are parallel with that produced by highly purified porcine CCK-PZ.

Fig 6 Cross reactivity of $C C K-P Z$ analogues in relation to their molecular structure. Figures give the amounts of each peptide required to produce the same inhibition (taken at $25 \%$ reduction) of antibody binding of labelled porcine CCK-PZ as produced by the pure hormone. Amino acid residues which differ from those of porcine $C C K-P Z$ are shown with double outlines.

Structures of CCK-PZ and gastrin beyond the C-terminal 12-amino acid sequence are not shown. Because the purity of the various peptides used is uncertain, these figures should be regarded as approximate.

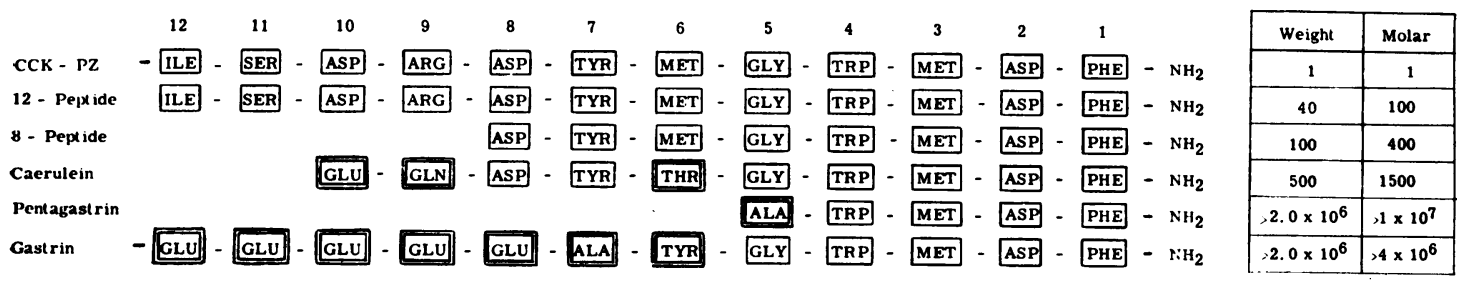

Fig 6 
purposes in these studies was derived from part of a batch of the very highly purified porcine hormone (batch of 11 November 1970, estimated biological potency approximately 3000 Ivy dog units per $\mathrm{mg}$ ) which had been obtained as a gift from Professor Mutt. This was weighed, dissolved in deionized water, divided into $1 \mu \mathrm{g}$ aliquots, freeze dried, sealed under nitrogen in glass ampoules, and kept at $-20^{\circ} \mathrm{C}$ until used. Although this 'standard' preparation appeared to give consistent results over many months and to possess immunoreactivity similar to that of a later batch of highly purified hormone (batch of August 1972) which had been divided into aliquots in the same way, tests against freshly dissolved preparations of CCK-PZ showed that the 'standard' preparation contained less immunoreactivity than expected. This deterioration seemed to have been produced mainly by the process of dissolving, freeze drying, and sealing in ampoules, as relatively little further loss of immunoreactivity could be detected during storage of the ampoules for several months. As both of the commercial preparations of CCK-PZ (Vitrum cholecystokinin and Boots pancreozymin) cross react with the highly purified hormone in a reproducible manner when freshly dissolved solutions of each are used, either one is potentially suitable for use as an alternative immunoassay standard. However, both preparations are impure and both are standardized by bioassay, so that there is likely to be some variation in potency from batch to batch. For this reason we have continued to use the aliquots of very highly purified hormone as standards, though recognizing that the absolute levels of serum hormone concentration may require division by some common factor when more suitable standard preparations of CCK-PZ become available.

NON-SPECIFIC EFFECTS OF SERUM ON THE ASSAY : RECOVERY OF CCK-PZ ADDED TO SERUM AND EFFECT OF EXOGENOUS HORMONE ON SERUM CCK-PZ LEVELS IN VIVO

Standard curves in the presence of undiluted serum were often not super-imposable on curves in buffer alone, whatever method was employed for separating free from antibody-bound hormone. The effect was most marked in the case of charcoal and resin methods of separation and was assumed to be due to non-specific protein-binding of the labelled hormone, though other factors may also be important. Dilution of serum to $1: 20$ before adding to the incubation mixture was found to decrease but not to abolish this effect. However, heating of the serum to $100^{\circ} \mathrm{C}$ for five to 10 minutes, to precipitate the serum proteins, centrifugation, and subsequent dilution of the supernatant $1: 20$ (or $1: 200$ for samples with a high CCK-PZ content) in phosphate buffer was found to abolish non-specific interference almost completely. Such heat treatment of serum might also help to avoid incubation damage by inactivating proteolytic enzymes, and was therefore carried out routinely on all serum samples. Assay standards were all dissolved in fasting serum devoid of detectable hormone, which had been boiled and diluted 1:20 in phosphate buffer. It was found that approximately $20 \%$ of normal fasting sera contained no detectable hormone and were suitable for use in this way.

Recovery of non-radioactive CCK-PZ added in amounts over a range of 10 to $1000 \mathrm{pg}$ per $\mathrm{ml}$ to aliquots of a single fasting serum sample, which were then boiled, diluted $1: 20$, and assayed in the usual way, ranged between 93.8 and $110 \%$. Boiling in buffer solutions for five to 10 minutes was similarly shown not to reduce CCK-PZ immunoreactivity.

Serum CCK-PZ levels were measured in three volunteers immediately after intravenous injection of 1.5 Crick-Harper-Raper units of CCK-PZ per kg body weight. Assuming immediate distribution in a plasma volume of $45 \mathrm{ml}$ per $\mathrm{kg}$, this dose would be expected to result in a serum CCK-PZ level of 2.56 ng per ml: actual measured levels were $1 \cdot 74,1 \cdot 70$, and $3.20 \mathrm{ng}$ per $\mathrm{ml}$ (mean 2.21), showing close agreement between the expected and measured levels.

\section{REPRODUCIBILITY}

The CCK-PZ levels were measured in 20 serum samples in two separate assays. The estimations were within $20 \%$ in seven cases, $20-100 \%$ in nine cases, and more than $100 \%$ in four cases $(104,113,150$, and $170 \%$ ). This degree of reproducibility was similar to that reported by Yalow and Berson (1970a) for gastrin.

\section{STUDIES IN MAN}

Serum samples were obtained from 30 healthy volunteers (hospital staff or students) after an overnight fast. Most of these subjects were between 20 and 40 years of age, so fasting serum samples were also obtained from 20 patients without upper gastrointestinal disorders, eg, recovering from minor surgical operations (age range 40-75), to represent an older age group.

The mean fasting serum CCK-PZ concentration in these 50 'normal' subjects was 60.4 picograms per $\mathrm{ml}$ (porcine CCK equivalent). The distribution of values was markedly skewed, however, so that the median value was much lower $(30 \mathrm{pg}$ per $\mathrm{ml})$ (fig 7). In all but two subjects the fasting level was less than $200 \mathrm{pg}$ per $\mathrm{ml}$. One subject had a level of $220 \mathrm{pg}$ per $\mathrm{ml}$ and one a level of $800 \mathrm{pg}$ per $\mathrm{ml}$. This 


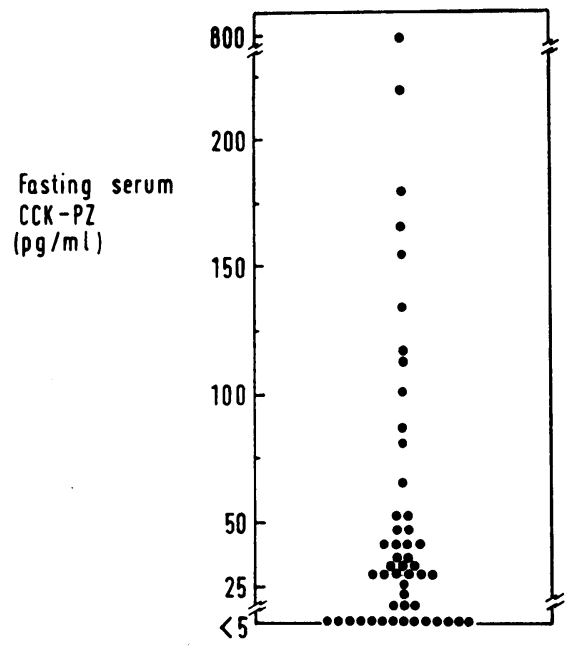

Fig 7 Distribution of fasting levels of CCK-like immunoreactivity in 50 adult subjects without known gastrointestinal disease.

latter subject was a generally fit 55-year-old man recovering satisfactorily from an operation on an inguinal hernia performed eight days previously, who had no history of other abdominal symptoms or previous alimentary disease. Even excluding this patient, fasting levels were significantly higher in 19 older subjects $(72.8 \pm 15.8 \mathrm{pg}$ per $\mathrm{ml})$ than in the 30 younger subjects $(27 \cdot 8 \pm 5 \cdot 3, \mathrm{P}<0 \cdot 0025)$.

\section{Discussion}

Cholecystokinin-pancreozymin is a particularly important member of the gastrointestinal hormone series, because of its powerful and varied actions on the gastrointestinal tract, particularly on the gallbladder, pancreas, and small intestine. Abnormalities of CCK-PZ secretion or action may be important in a variety of gastrointestinal disorders, for example, in pancreatic exocrine deficiency (Harvey, Dowsett, Hartog, and Read, 1973), coeliac disease (Low-Beer, Heaton, Heaton, and Read, 1971; Dimagno, Go, and Summerskill, 1972; Low-Beer, Harvey, Nolan, Davies, and Read, 1974), in patients who have undergone gastric operations (Johnson and McDermott, 1973), and in some patients with functional dyspepsia and the irritable bowel syndrome (Nebel and Castell, 1972; Resin, Stern, Sturdevant, and Isenberg, 1973; Harvey and Read, 1973). For this reason it is clearly desirable to develop assays capable of sensitive, accurate, and specific measurement of CCK-PZ levels in blood. Although sensitive bioassays have been developed (Berry and Flower, 1972; Johnson and McDermott, 1973), the technique of radioimmunoassay offers a much greater degree of sensitivity. This technique, however, is liable to a number of artefacts (Kirkham and Hunter, 1971) and full characterization of each antibody and standard used in the assay, together with recovery experiments and tests for non-specific interference, are essential for excluding such artefacts.

A number of groups have now reported the development of antibodies to CCK-PZ, but as yet there have been no detailed descriptions of the characterization of a radioimmunoassay suitable for applying to the study of CCK-PZ secretion in man. The assay of Young and colleagues (1969) achieved a high degree of sensitivity, but the levels of CCK-PZ in man reported in their preliminary report were considerably lower than those found using the assay described here. Such differences may be due to the nature of the antibody, for example, one that reacts less avidly with human CCK-PZ than with the porcine hormone, or to the labelled hormone or standards employed. The inter-conversion of weight and bioassay units in their report has been criticized as being imprecise (Berson and Yalow, 1972), and this might also contribute to the difference. The antibody developed by Go, Ryan, and Summerskill (1971) to porcine CCK-PZ differed from that used in our assay in showing no cross reaction with human CCK-PZ, and was presumably directed at a site on the CCK molecule where there are structural differences between the porcine and the human hormone. Reeder and his colleagues (1973), using an antibody raised in a rabbit, reported that in their assay the basal serum levels in five human volunteers ranged between 6900 and $23300 \mathrm{pg}$ per ml. Intravenous injection of $0.5 \mathrm{IDU} / \mathrm{kg}$ of CCK produced an apparent mean rise of $15.2 \mathrm{ng}$ per $\mathrm{ml}$ (expected: $3.70 \mathrm{ng}$ per $\mathrm{ml}$ ). These findings of unexpectedly high levels might be accounted for by the nature of the antibody used in their studies, and the extent of its cross reaction between human and porcine CCK-PZ, or possibly by the employment of relatively impure (approximately $17 \%$ ) hormone for use as tracer.

The cross reactivity data obtained in our study suggest that the rabbit antiserum MS6 reacts near the C-terminal end of the CCK-PZ molecule. However, the fact that pentagastrin cross reacts only very weakly and gastrin not at all, whereas caerulein, C-terminal octapeptide, and C-terminal dodecapeptide show progressively stronger cross reaction, indicates that the main antibody binding takes place over a considerable length of the CCK-PZ molecule, near but not at the $\mathrm{C}$-terminal end itself. Figures for cross-reactivity in relation to molecular structure are shown in figure 6. 
It is clear that the antibody reacts with molecules which resemble the C-terminal end of CCK-PZ. As biological activity resides in this end of the molecule, the minimum effective fragment for CCK-PZ-like activity being $\mathrm{C}$-terminal the 7 -amino acid sequence (Ondetti et al, 1970b), some cross reaction in this assay system for porcine CCK-PZ may be expected with CCK-PZ from different species. Thus, although absolute values for CCK-PZ levels in tissues or blood cannot be given for man or for animals other than the pig until pure CCK-PZ for each species is available for cross-reactivity tests, studies in different animals should be possible using this assay. Serial dilutions of endogenous human CCK-PZ, both from extracts of jejunal biopsy material and from postprandial serum, showed parallel inhibition curves with the highly purified porcine CCK-PZ. This antibody therefore, unlike that of Go et al (1971), is suitable for studies in man. However, as noted above, absolute values for levels of human CCK-PZ cannot yet be given, and all values are expressed in terms of the porcine hormone. The lack of cross reaction with gastrin, the only hormone apart from caerulein known to be structurally similar to CCK-PZ, means that this antibody (MS6) is specific for CCK-PZ as far as known intestinal hormones are concerned.

Although at the present time the lack of suitably characterized reference standards for either porcine or human CCK-PZ makes it difficult for workers in this field to compare the results of different assays or to say with certainty what the levels of endogenous human CCK-PZ are, approximate levels may be predicted. As CCK-PZ appears to be closely related to gastrin, both in terms of molecular structure and in function, some similarities in the patterns of secretion of the two hormones may be expected. Fasting levels for gastrin are generally found to be in the low picrogram range ( $<100 \mathrm{pg}$ per $\mathrm{ml})$ in most normal subjects (Yalow and Berson, 1970a; Hansky and Cain, 1969; Trudeau and McGuigan, 1971; Schrumpf and Sand, 1972; Stadil and Rehfeld, 1973) and the similar levels in the case of CCK-PZ, as found in this study, are not unexpected. As with gastrin, older subjects have apparently higher fasting levels of CCK-PZ, but as yet no explanation for this finding is apparent.

Exact figures for the expected peak levels of endogenous serum CCK-PZ after a normal meal are less easy to predict. Rapid injection of $75 \mathrm{Ivy}$ dog units $(25 \mu \mathrm{g})$ of CCK-PZ into a 70-kg man would produce a plasma CCK-PZ level of approximately $8 \mathrm{ng}$ per $\mathrm{ml}$, assuming initial distribution to take place solely in a plasma volume of $3000 \mathrm{ml}$. This dose of CCK-PZ is sufficient to produce gallbladder contraction in most normal subjects, so it is unlikely that the usual physiological stimuli would produce a peak blood CCK-PZ level much greater than $10 \mathrm{ng}$ per $\mathrm{ml}$. A further factor in the case of CCK-PZ is that because of the very short half-life in blood (Harvey, Dowsett, Hartog, and Read, 1973), and because CCK-PZ is released only after food enters the duodenum, exact peak levels are likely to depend as much on the rate of gastric emptying and smallintestinal transit as on the nature of the individual stimulus. Peak increments of CCK-PZ in the low nanogram range, eg, 1-20 $\mathrm{ng}$ per $\mathrm{ml}$, after normal physiological stimuli would not be unexpected, and peak increments within this range have been reported by most of the groups who have directly measured CCK-PZ release, whether by bioassay (Berry and Flower, 1971; Johnson and McDermott, 1973) or by radioimmunoassay (Go, Ryan, and Summerskill, 1971; Englert, 1973; Harvey, Dowsett, Hartog, and Read, 1973; Reeder, Becker, Smith, Rayford, and Thompson, 1973).

Most of the artefacts inherent in the radiomimunoassay method appear to have been excluded from the present assay, by the methods described. Measurement of structurally dissimilar circulating factors should be impossible when very highly purified hormone is used for labelling. Cross reaction with gastrin, the only other peptide with a similar C-terminal structure known to occur in man, is insignificant. Non-specific interference by serum factors appears to have been excluded by boiling and by dilution of the serum, as judged by the recovery experiments in vitro and in vivo. As the antibody appears to interact with the C-terminal (biologically active) end of the CCK-PZ molecule, bioactivity and immunoreactivity should agree when using the antibody. One or two problems still remain to be solved. As discussed above, no suitable standards for porcine or human CCK-PZ are currently available, so that absolute values for levels of this hormone cannot yet be given. Even so, if properly selected control groups are used, the measurement of differences in CCK-PZ levels in different clinical states and of changes in the level of CCK-PZ during physiological studies should be perfectly acceptable until well characterized and stable standard preparations become available. A further problem, which is somewhat more complex, is that CCK-PZ appears to be present in serum and in tissues in at least three separate molecular forms (Harvey and Dowsett, 1974), as is the case with gastrin (Yalow and Berson, 1970b; 1971; 1972; Gregory and Tracy, 1972; Rehfeld, 1972; Rehfeld and Stadil, 1973; Yalow and Wu, 1973). At present nothing is known of the relative immunoreactivity or biological potency of these different cholecystokinins, and as only one (the 33-amino acid CCK-PZ 
of Jorpes and Mutt) is currently available in pure form with a known molecular weight, absolute figures for the level of these various peptides cannot be given at the present time. Despite these problems the radioimmunoassay method has a number of advantages and should rapidly increase our knowledge of the factors controlling the secretion and action of cholecystokinin in normal circumstances and in disease states.

This work would have been impossible without the generous gifts of cholecystokinin-pancreozymin from Mr V. J. Birkinshaw and Dr J. Warwick Buckler (Boots Company Ltd) and from Professors J. E. Jorpes and V. Mutt (Karolinska Institute). Fragments and analogues of CCK-PZ were made available through the courtesy of $\mathrm{Dr} \mathrm{M}$. Ondetti and colleagues (Squibb Institute for Medical Research), Dr J. C. P. Weber (Farmitalia (UK) Ltd), and Dr J. S. Morley (ICI Ltd). Mr V. J. Birkinshaw (Boots Company Ltd), Dr F. J. Bourne (Veterinary Research Station, Langford), and Professor Bengt Ihre gave immense practical help with various aspects of the immunization programme. We thank the volunteers who provided serum for study and the physicians and surgeons who allowed us to study their patients. The work was supported by a grant from the Medical Research Council.

\section{References}

Adlercreutz, E., Pettersson, T., Adlercreutz, H., Gribbe, P., and Wegelius, C. (1960). Effect of cholecystokinin on duodenal tonus and motility. Acta med. scand., 167, 339-342.

Anastasi, A., Erspamer, V., and Endean, R. (1968). Isolation and aminoacid sequence of caerulein, the active decapeptide of the skin of Hyla caerulea. Arch. Biochem., 125, 57-68.

Berry, H., and Flower, R. J. (1971). The assay of endogenous cholecystokinin and factors influencing its release in the dog and cat. Gastroenterology, 60, 409-420.

Berson, S. A., and Yalow, R. S. (1972). Radioimmunoassay in gastroenterology. Gastroenterology, 62, 1061-1084.

Chey, W. Y., Hitanant, S., Hendricks, J., and Lorber, S. H. (1970). Effect of secretin and cholecystokinin on gastric emptying and gastric secretion in man. Gastroenterology, 58, 820-827.

Dahlgren, S. (1966). Cholecystokinin: pharmacology and clinical use. Acta chir. scand., Suppl., 357, p. 256-260.

Dimagno, E. P., Go, V. L. W., and Summerskill, W. H. J. (1972). Impaired cholecystokinin-pancreozymin secretion, intraluminal dilution and maldigestion of fat in sprue. Gastroenterology, 63, 25-32.

Dinoso, V. P., Jr., Meshkinpour, H., Lorber, S. H., Gutierrez, J. G., and Chey, W. Y. (1973). Motor responses of the sigmoid colon and rectum to exogenous cholecystokinin and secretin. Gastroenterology, 65, 438-444.

Dyck, W. P., Hall, F. F., and Ratliff, C. R. (1973). Hormonal control of intestinal alkaline phosphatase secretion in the dog. Gastroenterology, 65, 445-450.

Ekins, R. P., Newman, G. B., and O'Riordan, J. L. H. (1968). Theoretical aspects of 'saturation' and radioimmunoassay. In Radioisotopes in Medicine: In vitro Studies, edited by $\mathbf{R}$. L. Hayes et al, pp. 59-100. U.S. Atomic Energy Commission, Oak Ridge, Tenn.

Englert, E. (1973). Radioimmunoassay (RIA) of cholecystokinin (CCK). (Abstr.) Clin. Res., 21, 207

Fisher, R. S., Lipshutz, W., and Cohen, S. (1973). The hormonal regulation of pyloric sphincter function. J. clin. Invest., 52, 1289-1296.

Go, V. L. W., Ryan, R. J., and Summerskill, W. H. J. (1971). Radio- immunoassay of porcine cholecystokinin-pancreozymin. $J$. Lab. clin. Med., 77, 684-689.

Gregory, R. A., and Tracy, H. J. (1972). Isolation of two 'big gastrins' from Zollinger-Ellison tumour tissue. Lancet, 2, 797-799.

Grossi, F. B., Messini, B., Del Duca, T., Ricci, M., and Messini, M. (1966). Attivatà penistaltica di massa del colon in seginto a somministrazione di 'Cecekin'. Prospettive di azione omorali sulla mottlita del colon, Clin. ter., 37, 117-121.

Hales, C. N., and Randle, P. J. (1963). Immunoassay of insulin with Insulin-antibody precipitate. Biochem. J., 88, 137-146.

Hansky, J., and Cain, M. D. (1969). Radioimmunoassay of gastrin in human serum. Lancet, 2, 1388-1390.

Harper, A. A., and Raper, H. S. (1943). Pancreozymin, a stimulant of the secretion of pancreatic enzymes in extracts of the small intestine. J. Physiol. (Lond.), 102, 115-125.

Harvey, R. F., and Dowsett, L. (1974). Heterogeneity of immunoreactive cholecystokinin. (In preparation).

Harvey, R. F., Dowsett, L., Hartog, M., and Read, A. E. (1973). A radioimmunoassay for cholecystokinin-pancreozymin. Lancet, 2, 826-828.

Harvey, R. F., and Read, A. E. (1973). Effect of cholecystokinin on colonic motility and symptoms in patients with the irritablebowel syndrome. Lancet, 1, 1-3.

Hunter, W. M., and Greenwood, F. C. (1962). Preparation of iodine ${ }^{131}$ labelled human growth hormone of high specific activity. Nature (Lond.), 194, 495-496.

Ivy, A. C., and Oldberg, E. (1928). A hormone mechanism for gallbladder contraction and evacuation. Amer. J. Physiol., 86, 599-613.

Johnson, A. G., and McDermott, S. (1973). Sensitive bioassay of cholecystokinin in human serum. Lancet, 2, 589-591.

Jorpes, J. E., and Mutt, V., Eds. (1973). Secretin, Cholecystokinin, Pancreozymin and Gastrin (Handbook of Experimental Pharmacology), edited by O. Eichler et al, Vol. 34. Springer, Berlin.

Jorpes, J. E., and Mutt, V. (1966). Cholecystokinin and pancreozymin one single hormone? Acta physiol. scand., 66, 196-202.

Kirkham, K. E., and Hunter, W. M., Eds. (1971). Radioimmunoassay Methods. Churchill Livingstone, Edinburgh and London.

Low-Beer, T. S., Harvey, R., Nolan, D., Davies, R., and Read, A. (1974). Gallbladder emptying and its relation to endogenous cholecystokinin levels in coeliac disease. Biomedicine (Europ. J. clin. biol. Res.), in press.

Low-Beer, T. S., Heaton, K. W., Heaton, S. T., and Read, A. E. (1971). Gallbladder inertia and sluggish enterohepatic circulation of bile salts in coeliac disease. Lancet, 1, 991-994.

McGuigan, J. E. (1968). Antibodies to the carboxyl-terminal tetrapeptide amide of gastrin in guinea-pigs. J. Lab. clin. Med., 71, 964-970.

Moritz, M., Finkelstein, G., Meshkinpour, H., Fingerut, J., and Lorber, S. H. (1973). Effect of secretin and cholecystokinin on the transport of electrolyte and water in human jejunum. Gastroenterology, 64, 76-80.

Nasset, E. S. (1972). Succus entericus secretion stimulated by cholecystokinin and its C-terminal octapeptide (Abstr.). Fed. Proc., 31, 354.

Nebel, O. T., and Castell, D. O. (1972). Lower esophageal sphincter pressure changes after food ingestion. Gastroenterology, 63, 778-783.

Ondetti, M. A., Plušcec, J., Sabo, E. F., Sheehan, J. T., and Williams, N. (1970). Synthesis of cholecystokinin-pancreozymin. I. The C-terminal dodecapeptide. J. Amer. chem. Soc., 92, 195-199.

Ondetti, M. A., Rubin, B., Engel, S. L., Pluscec, J., and Sheehan, J. T. (1970). Cholecystokinin-pancreozymin: recent developments. Amer. J. dig. Dis., 15, 149-156.

Reeder, D. D., Becker, H. D., Smith, N. J., Rayford, P. L., and Thompson, J. C. (1973). Measurement of endogenous release of cholecystokinin by radioimmunoassay. Ann. Surg., 178, 304-310.

Rehfeld, J. F. (1972). Three components of gastrin in human serum Gel filtration studies on the molecular size of immunoreactive serum gastrin. Biochim. biophys. Acta (Amst.), 285, 364-372.

Rehfeld, J. F., and Stadil, F. (1973). Gel filtration studies on immunoreactive gastrin in serum from Zollinger-Ellison patients. Gut, 14, 369-373.

Resin, H., Stern, D. H., Sturdevant, R. A. L., and Isenberg, J. I. (1973). Effect of the C-terminal octapeptide of cholecystokinin on lower esophageal sphincter pressure in man. Gastroenterology, 64, 946-949.

Schrumpf, E., and Sand, T. (1972). Radioimmunoassay of gastrin with activated charcoal. Scand. J. Gastroent., 7, 683-687. 
Stadil, F., and Rehfeld, J. F. (1973). Determination of gastrin in serum: an evaluation of the reliability of a radioimmunoassay. Scand. J. Gastroent., 8, 101-112.

Trudeau, W. L., and McGuigan, J. E. (1971). Relations between serum gastrin levels and rates of gastric hydrochloric acid secretion. New Engl. J. Med., 284, 408-412.

Yalow, R. S., and Berson, S.'A. (1970a). Radioimmunoassay of gastrin. Gastroenterology, 58, 1-14.

Yalow, R. S., and Berson, S. A. (1970b). Size and charge distinctions between endogenous human plasma gastrin in peripheral blood and heptadecapeptide gastrins. Gastroenterology, 58, 609-615.
Yalow, R. S., and Berson, S. A. (1971). Further studies on the nature of immunoreactive gastrin in human plasma. Gastroenterology 60, 203-214.

Yalow, R. S., and Berson, S. A. (1972). And now, 'big, big' gastrin. Biochem. biophys. Res. Commun., 48, 391-395.

Yalow, R. S., and Wu, N. (1973). Additional studies on the nature of big big gastrin. Gastroenterology, 65, 19-27.

Young, J. D., Lazarus, L., Chisholm, D. J., and Atkinson, F. F. V. (1969). Radio-immunoassay of pancreozymin cholecystokinin in human serum. J. nucl. Med., 10, 743-745. 